\title{
The Effect of Net Income and Other Comprehensive Income on Future's Comprehensive Income With Attribution of Comprehensive Income as Moderating Variable
}

\author{
Marhaendra Kusuma ${ }^{1}$, Diana Zuhroh ${ }^{2}$, Prihat Assih $^{3} \&$ Grahita Chandrarin ${ }^{1}$ \\ ${ }^{1}$ Graduate School, University of Merdeka Malang, Indonesia \\ ${ }^{2}$ Master Program in Accounting, University of Merdeka Malang, Indonesia \\ ${ }^{3}$ Faculty of Economics and Business, University of Merdeka Malang, Indonesia \\ ${ }^{4}$ Graduate School, University of Merdeka Malang, Indonesia \\ Correspondence: Diana Zuhroh, Master Program in Accounting, University of Merdeka Malang, Indonesia. E-mail: \\ diana.zuhroh@unmer.ac.id
}

Received: August 31, 2020

Accepted: December 10, 2020

Online Published: January 20, 2021

doi:10.5430/ijfr.v12n3p205

URL: https://doi.org/10.5430/ijfr.v12n3p205

\begin{abstract}
This study aims to examine the effect of net income and other comprehensive income on the total of future's comprehensive income with attribution of earning as a moderating variable. It also tests whether comprehensive income is more persistent than Net Income and whether re-measurement of the defined program is the highest predictive power for future CIs. The dependent variable was Comprehensive Income $_{t+1}$, and the independent variables were Net Income and Other Comprehensive Income. Data sources were financial statements 2014-2018 of 367 companies listed in Indonesia Stock Exchange. The empirical evidence were 1).Net income and other comprehensive income can predict future comprehensive income, 2). The CI attribution can improve the ability of NI and $\mathrm{OCI}$ in predicting future CI. 3). Net income is more persistent than other comprehensive income, 4). The defined program is the highest predictive power for future CIs.
\end{abstract}

Keywords: net income, comprehensive income, other comprehensive income, attribution of earning

\section{Introduction}

Before 2012 Indonesian accounting standards referred to US-GAAP accounting principles, and after 2012 turned to International Financial Reporting Standards (IFRS). There were significant differences in Indonesian accounting standards before and after the convergence of IFRS, one of which is related to the format of the presentation of the Income Statement. The Basic Framework for the preparation and presentation of Financial Statements in paragraphs 3.05 and 3.07 (IAI, 2018) states that financial statements are considered as high quality if they are relevant to user needs. The value of relevance is indicated by the ability to predict future results. By changing the position of the OCI presentation, from the Statement of Changes in Equity to the Income Statement and adding profit attributions to the parent and non-controlling, will this increase the value relevance compared to the previous income statement format?

A study conducted by Shi, Wang, \& Zhou (2017) concluded that the purpose of moving the location of OCI presentation from balance sheet equity to the income statement is to increase the transparency of financial statements and the predictive power of earnings for an estimated stock price. This is caused by the fact that users of financial statements use OCI in financial analysis for decision making (H. J. Kim \& Yoon, 2019; Schaberl \& Victoravich, 2015. Likewise, Elbakry, Nwachukwu \& Abdou (2017) concluded that the ability of accounting information in predicting future earnings increased after converging with IFRS (compared to before while still using the previous standard).

The addition of OCI information in the income statement increases the value of relevance for users, creates changes in the fair value of assets from their historical records, increases transparency, and presents a better overall financial statement (Kanagaretnam, Mathieu, \& Shehata, 2009). Research conducted by Sajnóg (2017), and Saymeh et al. (2019) concluded that total comprehensive income has significant predictive power on future comprehensive income and profitability. Jones \& Smith (2011) also concluded that the presentation of OCI in the income statement was able to 
increase the value of the relevance of financial statements as indicated by the ability to increase the predictive power of future earnings.

However, the results of the study conducted by Banks, Hodgson, \& Russell (2018) show that the information content of NI remains greater than the aggregate of $\mathrm{CI}$ (which is the sum of NI and OCI). Changes in locations of OCI reporting are considered not to increase the relevance value which measured in predictive power on abnormal stock returns. In general, this study concluded that the presentation of $\mathrm{OCI}$ in the income statement, either by component or in aggregate did not increase the value of relevance that is significant for users because NI is still considered better than OCI in terms of the predictive power of return.

The results of a study by Chebaane \& Ben (2014) concluded that the level of relevance of financial statements is influenced not only by accounting standards that are convergent with IFRS but also by laws that protect the rights of minority investors. The presentation of information about earnings and equity attributions to owners is based on economic unit theory and has been proven to empirically increase the value of financial reporting relevance and is useful for predicting the company's market value and stock returns (So \& Smith, 2009). Recent research by Francesco (2018) shows the same result that the presentation of attributions to non-controlling interests provides additional value in predicting stock prices and market capitalization, as well as financial performance (Yan \& He, 2018). The opposite results obtained by Lopes, Lourenço, \& Soliman (2013) that whether or not there was information about earnings attributions to non-controlling interests in the financial statements, wherever the location of the information, and whatever the amount, it was not an important concern for users of financial statements.

This research was triggered by a significant change in the format of the presentation of the income statement since the enactment of the Financial Accounting Standards which began effective since June 1, 2012, and converges with IFRS as of January 1, 2009. The first change was the addition of Other Comprehensive Income (OCI) information that was reported along with the net income (NI) of the current year so that the name of the report also changed to "Statement of Profit and Loss and Other Comprehensive Income" from what was originally only called "Income Statement", where OCI is reported in the Statement of Changes in Equity. The second change is the allocation of profits or earnings attributions to the owners of the parent entity and non-controlling interests, both from NI and OCI.

This research also conducted based on the inconsistencies of the results of previous studies related to the value of the relevance of OCI and attribution to owners. In more detail, the purpose of this study is to obtain empirical evidence: (1). whether NI and OCI are able to predict CI in the future, (2) whether the presence of attribution CI is able to improve the ability of NI and OCI in predicting future CI, (3) whether CI is more persistent than NI, and (4) Does re-measurement of the defined benefit program have the highest predictive power for future CIs. The results of this study provide input for users of financial statements regarding the benefit of changing the format of the presentation of the income statement, especially the value of relevance for information about other comprehensive income (OCI) and the attribution of earnings to owners. The next benefit is providing input to the accounting standards authority in Indonesia regarding the addition of OCI components that have not been regulated in accounting standards. From a theoretical point of view, this study provides empirical evidence that clarifies the "distribution of NI and CI" to the two types of company owners according to the proportion of share ownership. For investors, the result of this study provides input for making investment decisions, particularly in assessing financial performance and future investment returns.

\section{Theoretical Review}

The change in the format of the income statement presented in the new accounting standard adds not only OCI but also the profit attribution policy (either NI profit or CI profit) to parent company and non-controlling owners. However, research in this area is still rare, especially related to the role of moderating earnings attributions to increase the value relevance of income statement information. Previous research, so far, only tested the value of the relevance of OCI information in the income statement without involving earnings attribution policies (Saymeh, 2019; Elbakry et al., 2018; Banks et al., 2018; Shi and Zhou, 2017; Sajnog, 2017; Schaberl and Victoravich, 2015; Jones and Smith, 2011; Kanagaretnam et al., 2009). Research on earnings attribution has been carried out by Francesco (2018), Yan and He (2018), and Lopes (2013), but all three have not linked earnings attributions to OCI and the ability to predict future CIs.

In subsequent developments, $\mathrm{OCI}$ items were added and the addition responded by changes in accounting standards. Of the 5 OCI components, several previous studies did not involve all OCI items. For example, Banks et al. (2018) research involves four items: revaluation, financial assets, hedging, and translation of financial statements, Kanagaretnam et al., (2009) only three items: financial assets, hedging, financial statement translation. Meanwhile, 
the research conducted by Kubota et al., (2013) it only involved two items: financial assets and financial statement translation), likewise, Yousefinejad (2017) involved revaluation and financial assets. Meanwhile, Jones and Smith's (2011) research involves four items: financial assets, translation, hedging, and retirement benefits. Thus, the weaknesses of previous studies are a). does not involve profit attributions, and b) of 5 OCI items, not all of them are included as research variables. Meanwhile, in accounting standards in Indonesia, there are 5 OCI component items, and in this study, all of them are involved.

\subsection{Grand Theory}

The grand theory underlying this research was agency theory (Jensen \& Meckling, 1976). By presenting comprehensive income and net income in the income statement, as well as presenting profit attributions to the parent owner and non-controlling interests, this will further increase transparency and quality of information and reduce information asymmetry. Studies conducted by Lin \& Rong (2012) show that the presentation of OCI can reduce earnings management practices and also increase transparency and value relevance (Rees \& Shane, 2012). A study by López-Quesada et al., (2018) concluded CI is positively correlated with good corporate governance and reflects the source of value creation.

The second grand theory underlying this research is the institutional theory (Dimaggio, Powell, \& Powell, 2012). This theory stated that pressure from the government and professional body influences organizational behavior to guarantee the legitimacy of organizational operations. The study of Yousefi Nejad \& Ahmad (2017) and Kubota et al. (2011) concluded that additional information about OCI and its components in the income statement proved to be useful for investors for decision making, related to their ability to predict stock prices. The use of Institutional Theory is based on the facts in Indonesia that the regulations established by the Indonesian government and the Indonesian Accountants Association (IAI), in this case, the convergence of SAK to IFRS will be followed by public entities in Indonesia. Accordingly, this compliance will also be related to the presentation of the income statement which includes additional OCI component information and profit attribution to the owner.

\subsection{Literature Review and Hypothesis Development}

The value of the relevance of net income and other comprehensive income.

Other comprehensive income is gains or losses that have not been realized due to the difference between the value of recorded assets and liabilities with fair value. Comprehensive income includes all measures of income, i.e. the sum of traditional net income (NI) and also the effects of changes recorded in other comprehensive income (OCI) (Gazzola $\&$ Amelio, 2014). Other comprehensive income components according to Indonesian Accounting Standard (PSAK) No.1, consist of: (1). Changes arising from the revaluation of tangible fixed assets or revaluation, (2). The difference between the value of recorded financial assets available for sale and their fair value presented in the financial statements, (3). The present value of cash received or paid in the future for cash flow hedges, (4). The present value of the payment of pension contributions, especially the defined benefit plan, and (5). Changes to the presentation of financial statements of foreign business activities from foreign currencies to rupiah.

Comprehensive income is more indicative of current conditions because it also reports OCI which is unrealized revenue that arises due to volatility in market conditions (Jones \& Smith, 2011), not because of management performance (Khan \& Bradbury, 2015). Comprehensive income theory holds an approach to the recognition and measurement of all-inclusive income, where all fair value measurements are recognized in revenue, both realized and unrealized (Hodgson \& Russell, 2014). OCI reflects changes in the fair value of assets, most of which consist of unrealized gains/losses and are influenced by external market factors. All changes in assets and liabilities other than those involving transactions with owners must be reported (Du Ning, Kevin Stevens, 2015). OCI presentations can increase the use-value of financial statements (Kanagaretnam et al., 2009), increase dividend payments and tax aggressiveness (Chen \& Gavious, 2016), increase audit procedures and increase audit (Ding, 2019), OCI that is involved in calculating profitability using ROA is proven to be able to shorten the audit report lag and encourage the presentation of financial reports on time (Fujianti and Satria, 2020), and increase the potential for practice earnings management (Zhao, Zhao, \& Wei, 2018).

A study concluded that NI was more informative than OCI related to the prediction of cumulative abnormal return (Banks et al., 2018; Hodgson \& Russell, 2014). Meanwhile, other studies concluded that OCI has low predictive power in estimating future net income and future cash flow, NI is more predictive than OCI (Jones \& Smith, 2011). Although the difference is not significant, NI is more predictive in assessing stock price changes compared to OCI (Kubota et al., 2011; Yousefi Nejad \& Ahmad, 2017; Humayun Kabir \& Laswad, 2011; Kanagaretnam et al., 2009); Būmane, 2018), Steinberg \& Forscher, 2014. That means, NI is more predictive than OCI because NI is a real 
income that has been realized, whereas OCI has not been realized due to changes in fair value and volatility in market conditions (not due to managerial performance results). Based on the conclusions of these studies, the hypotheses in this study is:

\section{H1: NI and OCI can predict CI in the future.}

\section{Earnings Attribution to the Owner and Aggregate Comprehensive Income.}

Earnings attribution is to divide the profits obtained, both NI and CI to majority shareholders and non-controlling owners (Yahaya, K. A., Fagbemi, TO and Oyeniyi, 2015). Empirical evidence from a previous study shows that the presentation of earnings attributions is an effort to the transparency of financial statements (Yahaya, KA, Fagbemi, TO and Oyeniyi, 2015). It increases the value of financial statements related to financial performance assessment (Yan \& He, 2018) and the principle of fairness and attention to the minority as well as affecting the market value of the company (Francesco, 2018) and returns (So \& Smith, 2009).

Presentation of the income statement in which there is additional information on OCI components, attributions of NI and OCI earnings to owners of the parent entity (majority shareholder) and noncontrolling interests (minority shareholders) will be more informative and quality (Chebaane \& Ben, 2014), more transparent (Shi et al., 2017). In addition, this informs the actual and unrealized revenues as the impact of changes in assets overvaluation to fair value (Du Ning, Kevin Stevens, 2015). This makes it easy for users to predict future earnings, both simultaneous profits in the form of comprehensive income, and partial profits in the form of NI and OCI (Jones \& Smith, 2011). This earnings prediction is used as input for users of financial statements in making decisions. In other words, the presentation of OCI and attribution of the owner's earnings to the income statement can increase the value of relevance, especially the ability to predict future earnings (Lewellen \& Resutek, 2019).

Previous research has shown that predictive power is better when aggregate is decomposed into its constituent items (Hodgson \& Russell, 2014; Banks et al., 2018); while Kubota et al., (2011) concluded that OCI components are more relevant in valuation and prediction than OCI in the aggregate. The study conducted by Kumari \& Mishra (2018), Hafij Ullah Mohammad (2013) also concluded, that the prediction of future earnings will increase when earnings are decomposed into accrual earnings and operating cash flows compared to aggregate earnings. Meanwhile, Willett (2016) research results show that when CI is decomposed into NI and OCI, it is proven to be more able to increase the relevance value of OCI. In relation to the decomposed comprehensive income, previous studies also found empirical evidence that the influence of attribution to owner on the company's market value and stock returns is greater than equity and profit or loss are presented without attribution (So and Smith, 2009). Based on these explanations, the second hypothesis of this study was:

$\mathrm{H} 2$ : The presentation of $\mathrm{CI}$ attribution can improve the ability of NI and $\mathrm{OCI}$ in predicting future CI.

\section{NI and CI Persistence.}

The influence of OCI on returns is even greater when OCI is presented in equity than in the income statement (Schaberl \& Victoravich, 2015). Similar results were obtained by DJ Chambers and Linsmeier TJ, (2007); Rees \& Shane, 2012, and Hodgson \& Russell (2014) that the presentation of OCI in the comprehensive income statement together with NI makes it easier for users to assess performance and another decision making, rather than being presented in the statement of changes in equity. Doukakis research (2010) shows that current ROE has the ability to predict future ROE. The decomposition of earnings into operational and non-operational components has more predictive power over the performance of future entities as measured by ROE, compared to earnings in the aggregate. The more persistent the earnings component, the more it can predict the ROE. After the adoption of IFRS in Greece, the persistence and predictive power of earnings (aggregate and decomposition) decreased compared to the period before adoption.

Research on the American capital market over a long period concluded that earnings and cash flow can be used to predict future earnings and have high persistence (Nam, 2019). But other studies have different results that OCI has a weak predictive value in estimating future net income (Jones \& Smith, 2011). Studies by Humayun Kabir \& Laswad, (2011) concluded that NI is more predictive than total comprehensive income (NI plus OCI) in predicting the next period of NI. The predictive power of earnings as an element of financial reporting quality, especially the value of relevance is shown from the level of persistence. Studies in Latvia showed that NI and OCI in the previous period were able to predict CI in the next period (Būmane, 2018), and study about high earnings persistence shows that the profit is sustainable for a long-term period (Fanani, 2010). NI's net income is more persistent than the total comprehensive income of empirical evidence in Canada (Kanagaretnam et al., 2009). Persistence has a direct impact on earnings predictability, and both are influenced by total revenue, company size, and income diversification (Canina \& Potter, 
2019). Based on these explanations, the third hypothesis of this study is:

H3: Comprehensive income is more persistent than net income.

\section{Value Relevance of Each OCI Component.}

The results of research by Moghaddam \& Aslani (2018) indicate that aggregate comprehensive income is more able to predict stock returns than to be separated in the cash and accrual components. Meanwhile according to Doukakis, (2010), when CI is decomposed into operational and non-operational, it turns out to be more predictive than aggregate $\mathrm{CI}$ in the ability to explain the financial performance of an entity in the future. Hodgson \& Russell (2014) also conclude that the decomposition of OCI to its components is more predictive than OCI in the aggregate. In aggregate, OCI has a low persistence value, but the OCI component that has a relationship with future earnings is cash flow hedges with a negative relationship direction. This is due to cash flow hedges eliminating the effects of price movements on company operations (Rees \& Shane, 2012). The cash flow hedging OCI component has better predictability of return than other OCI components (Banks et al., 2018).

Specific studies for types of state-owned companies in Iran by (Steinberg \& Forscher, 2014) conclude that the OCI component of fixed asset revaluation and foreign currency adjustments are superior to other OCI components in improving CI's ability to predict future earnings. The OCI component is formed from the fair value accounting policy which causes changes in the carrying value of assets to follow the current fair value, and the OCI component that is responsive to changes in fair value is available for sale financial assets. Although not yet realized, changes in the fair value of financial assets available for sale have been proven to have a significant effect on stock prices and returns (Kanagaretnam et al., 2009).

In Indonesia, Company Law requires companies to have a pension benefit program for their employees. Generally, the larger the company, the more the number of employees, and then the greater the number of pension contributions. In addition, it is certain that OCI items, namely pension benefits, always appear in the annual report of public companies in Indonesia, while not so for other OCI items. Therefore, there is a possibility that the benefit program is better able to predict future income than other OCI items. Based on this fact, the fourth hypothesis of this study is:

H4: Re-measurement of the defined program have the highest predictive power for future CIs, compared to the other four OCI components.

\section{Research Method}

To answer research questions, the following research model are arranged:

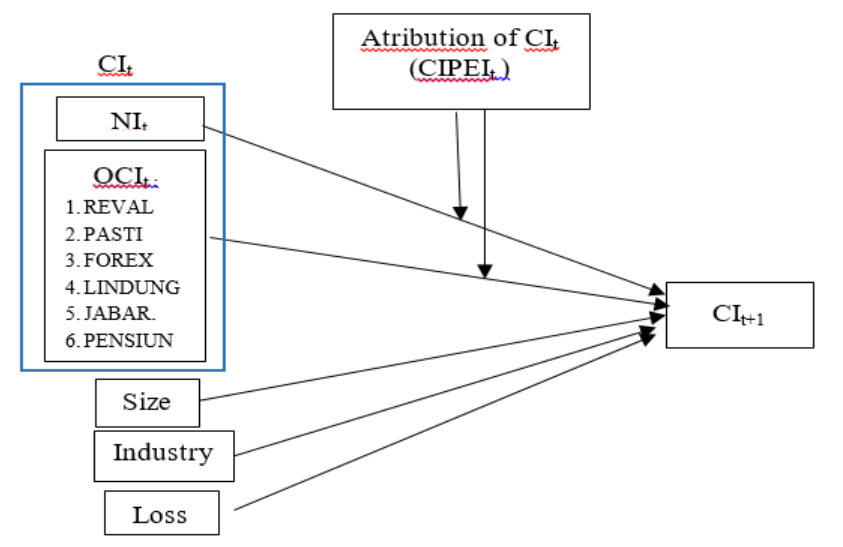

Figure 1. Research Model

\subsection{Research Variables}

The independent variables are OCI and NI, while the Attribution of CI to shareholders is a moderating variable. The OCI variable consists of 6 elements, namely: Changes in the revaluation surplus (REVAL), Re-measurement of the defined benefit program (PASTI), Gains and losses from re-measurement of financial assets as 'available for sale' (FOREX), the effective portion of gains or losses from hedging (LINDUNG), and Gains or losses arising from 
foreign business activities (JABAR). As explained above, the determination of CI attribution as a moderating variable is based on reason, as also explained earlier, it can increase the predictability of NI and OCI in estimating CI in the future. Company size (Size), company business field (Industry), and negative net income (Loss) condition were used as control variables. Table 1 presents the measurement of the variables and their respective dimensions.

\subsection{Population and Research Samples}

The population in this study were all companies listed on the Indonesia Stock Exchange. The data source was the company's annual report for the period 2014 - 2018. Samples were selected by purposive sampling method, with the following criteria: (1). companies successively publish financial statements for the period 2014 - 2018 (excluding new IPOs after 2014), (2) the financial statements are presented in Rupiah, (3) companies that provide other comprehensive income information (detailed and aggregate) and attribution of profit in the statement of comprehensive income. Based on these criteria, the number of samples that meet the requirements were 365 companies or 1,835 firm years.

Table 1. Measurement of variable

\begin{tabular}{|c|c|c|}
\hline Variables \& Notations & Measurement & Dimension \\
\hline \multicolumn{3}{|l|}{ Dependent Variable } \\
\hline \multirow{2}{*}{$\begin{array}{l}\text { Comprehensive income } \\
\text { for the period } t+1\left(\mathrm{CI}_{\mathrm{t}+1}\right) \text {. }\end{array}$} & $\mathrm{NI}_{\mathrm{t}+1}+\mathrm{OCI}_{\mathrm{t}+1}$ & Predictions of future earnings \\
\hline & Total Assets t $_{t+1}$ & $\begin{array}{l}\text { (Comprehensive income for the } \\
\text { period } t+1\}\end{array}$ \\
\hline \multicolumn{3}{|c|}{ Independent Variable } \\
\hline \multirow[t]{2}{*}{ Net income ( NI). } & $\mathrm{NI}_{\mathrm{t}}$ & Current year income aggregate. \\
\hline & Total Asset $_{t}$ & \\
\hline \multirow{2}{*}{$\begin{array}{l}\text { Other Comprehensive } \\
\text { Income }(\mathrm{OCI})\end{array}$} & $\mathrm{OCI}_{\mathrm{t}}$ & Other Comprehensive Income \\
\hline & Total Asset ${ }_{t}$ & aggregate period $t$ \\
\hline \multicolumn{3}{|l|}{ Elements of OCI } \\
\hline \multirow[t]{2}{*}{ REVAL $_{\mathrm{t}}$} & REVAL $_{\mathrm{t}}$ & Changes in the revaluation \\
\hline & Total Asset ${ }_{t}$ & surplus period $t$ \\
\hline \multirow{2}{*}{ PASTI $_{t}$} & PASTI $_{t}$ & \multirow[t]{2}{*}{ Re-measurement of the defined benefit program } \\
\hline & Total Asset $_{\mathrm{t}}$ & \\
\hline \multirow[t]{2}{*}{ FOREX $_{t}$} & FOREX $_{\mathrm{t}}$ & \multirow{2}{*}{$\begin{array}{l}\text { Gains and losses from remeasurement of } \\
\text { financial assets as 'available for sale' period t. }\end{array}$} \\
\hline & Total Asset $_{t}$ & \\
\hline \multirow[t]{2}{*}{ LINDUNG $_{\mathrm{t}}$} & LINDUNG $_{\mathrm{t}}$ & \multirow{2}{*}{$\begin{array}{l}\text { The effective portion of gains or losses from } \\
\text { hedging instruments for the purpose of hedging } \\
\text { cash flows for the period t. }\end{array}$} \\
\hline & Total Asset $t_{t}$ & \\
\hline \multirow[t]{2}{*}{$\mathrm{JABAR}_{\mathrm{t}}$} & $\mathrm{JABAR}_{\mathrm{t}}$ & \multirow{2}{*}{$\begin{array}{l}\text { Gains or losses arising from foreign business } \\
\text { activities t. }\end{array}$} \\
\hline & Total Asset ${ }_{\mathrm{t}}$ & \\
\hline \multicolumn{3}{|c|}{ Moderating Variable } \\
\hline \multirow[t]{2}{*}{ CI Attribution $\left(\mathrm{CIPEI}_{\mathrm{t}}\right)$} & $\mathrm{CIPEI}_{\mathrm{t}}$ & \multirow{2}{*}{$\begin{array}{l}\text { Comprehensive income attributable to owners of } \\
\text { the parent, period } t\end{array}$} \\
\hline & Total Asset $_{\mathrm{t}}$ & \\
\hline \multicolumn{3}{|c|}{ Control Variable } \\
\hline Company size (Size) & Ln Total Asset period $\mathrm{t}$ & \\
\hline \multirow{4}{*}{$\begin{array}{l}\text { Industrial type } \\
\text { (INDUSTRY) }\end{array}$} & Variabel dummy & \\
\hline & Dummy Variable & \\
\hline & $1=$ manufacture & \\
\hline & $0=$ non manufacture & \\
\hline \multirow{3}{*}{$\begin{array}{l}\text { Negative net income } \\
\text { (LOSS) }\end{array}$} & Variable dummy & \\
\hline & $1=$ negative net income & \\
\hline & $0=$ if not & \\
\hline
\end{tabular}




\subsection{Data Analysis}

Hypothesis 1 built in this study is: NI is more able to predict CI than OCI. To test the H1, the following model is built:

$$
\mathrm{CI}_{\mathrm{t}+1}=\alpha_{0}+\alpha_{1} \mathrm{NI}_{\mathrm{t}}+\alpha_{2} \mathrm{OCI}_{\mathrm{t}}+\alpha_{3} \text { INDUSTRY }+\alpha_{4} \mathrm{SIZE}_{\mathrm{t}}+\alpha_{5} \mathrm{LOSS}_{\mathrm{t}}+\mathrm{e}
$$

$\mathrm{H} 1$ is accepted if the model has a significant $\mathrm{F}$ value (feasible), and is supported by the coefficient values $\alpha_{1} \mathrm{NI}_{\mathrm{t}}$ and or $\alpha_{2} \mathrm{OCI}_{t}$ with a significance of $t$ less than $1 \%$ or $5 \%$ (Banks et al., 2018; Canina \&Porter 2019).

Hypothesis 2 of this study is: Presentation of CI attributions increases the ability of NI and OCI in predicting future CI. To test the $\mathrm{H} 2$ the following model is built:

$$
\mathrm{CI}_{t+1}=\beta_{0}+\beta_{1} \mathrm{NI}_{\mathrm{t}}+\beta_{2} \mathrm{OCI}_{\mathrm{t}}+\beta_{3} \mathrm{NI}_{\mathrm{t}} * \mathrm{CIPEI}_{\mathrm{t}}+\beta_{4} \mathrm{OCI}_{\mathrm{t}} * \mathrm{CIPEI}_{\mathrm{t}}+\beta_{5} \mathrm{INDUSTRY}+\beta_{6} \mathrm{SIZE}_{\mathrm{t}}+\beta_{7} \mathrm{LOSS}_{\mathrm{t}}+\mathrm{e}
$$

$\mathrm{H} 2$ is accepted if the model has significant $\mathrm{F}$ and the coefficients of $\beta_{1} \mathrm{NI}_{\mathrm{t}}$ and $\beta_{2} \mathrm{OCI}_{\mathrm{t}}$ in equation 2 are greater than the coefficients of $\alpha_{1} \mathrm{NI}_{\mathrm{t}}$ and $\alpha_{2} \mathrm{OCI}_{\mathrm{t}}$ in equation 1 (Banks et al., 2018).

Hypothesis 3 built in this study is that $\mathrm{CI}$ is more persistent than NI, and to test it the following model is built:

$$
\begin{gathered}
\mathrm{NI}_{\mathrm{t}+1}=\beta_{0}+\beta_{1} \mathrm{NI}_{\mathrm{t}}+\beta_{2} \mathrm{NI}_{\mathrm{t}-2}+\beta_{3} \mathrm{NI}_{\mathrm{t}-3}+\beta_{4} \mathrm{INDUSTRY}+\beta_{5} \text { SIZE }_{\mathrm{t}}+\beta_{6} \text { LOSS }_{\mathrm{t}}+\mathrm{e} \\
\mathrm{CI}_{\mathrm{t}+1}=\alpha_{0}+\alpha_{1} \mathrm{CI}_{\mathrm{t}}+\alpha_{2} \mathrm{CI}_{\mathrm{t}-2}+\alpha_{3} \mathrm{CI}_{\mathrm{t}-3}+\alpha_{4} \mathrm{INDUSTRY}+\alpha_{5} \text { SIZE }_{\mathrm{t}}+\alpha_{6} \text { LOSS }_{\mathrm{t}}+\mathrm{e}
\end{gathered}
$$

$\mathrm{H} 3$ is accepted if models 3.a and 3.b have a significant $\mathrm{F}$ (which means that model 3 is feasible), and adjusted R2 equation 3.b is greater than adjusted R2 equation 3.a. This step is in line with the steps used in previous studies including Canina \& Potter (2019), Kubota et al, (2011), Hafij Ullah Mohammad (2013), and Humayun Kabir \& Laswad, (2011).

Hypothesis 4 built in this study is: The re-measurement of the defined benefit program (the pension program) has the highest predictive power for future CIs, compared to four other OCI components. To test the H4 the following model is built:

$$
\begin{aligned}
\mathrm{CI}_{\mathrm{t}+1}= & \beta_{0}+\beta_{1} \text { REVAL }_{\mathrm{t}}+\beta_{2} \text { PASTI }_{\mathrm{t}}+\beta_{3} \text { FOREX }_{\mathrm{t}}+\beta_{4} \text { LINDUNG }_{\mathrm{t}}+ \\
& \beta_{5} \mathrm{JABAR}_{\mathrm{t}}+\beta_{6} \text { INDUSTRY }_{\mathrm{t}}+\beta_{7} \text { SIZE }_{\mathrm{t}}+\beta_{8} \text { LOSS }_{\mathrm{t}}+\mathrm{e}
\end{aligned}
$$

$\mathrm{H} 4$ is accepted if the model has a significant $\mathrm{F}$ and the coefficient $\beta_{3}$ PASTI $\mathrm{t}$ is greater than the coefficients of other variables.

\section{Result and Discussion of the Result}

\subsection{Results of the Research}

Based on the descriptive analysis, the composition of the sample by industry type were 195 manufacturing companies (53.1\%), 172 non-manufacturing companies (46.9\%) with details: 145 service companies (39.5\%) and 27 trading companies (7.4\%). OCI items found in all of the companies sampled in this study are defined as post-retirement benefits (100\%), this is due to obligations under company law in Indonesia. The next is profit/loss of available-for-sale financial assets (73 companies or 20\%), and, this type of OCi is generally owned by companies in the financial sector, such as banks, insurance companies and other financial institutions. These companies invest funds collected from the public as productive assets, including financial assets such as shares, with the fair value that fluctuates greatly depending on market conditions.

The next OCI owned by companies is the translation of financial statements (62 companies or 17\%), and the types of companies that most have this OCI items are manufacturing companies that have overseas businesses. OCI item that companies rarely have is cash flow hedges (20 companies or 5\%), and it is generally owned by companies in the financial sector. To avoid loss of cash value due to fluctuations in the rupiah exchange rate, finance companies try to secure their cash investments through a hedging contract scheme.

OCI items that have the highest average nominal value of rupiah and are relatively rarely carried out are the revaluation of fixed assets. The companies that mostly revalued fixed assets were real estate, property, infrastructure, and construction, followed by the banking sector and property rental services companies. This is due to the very high value of the fixed assets owned by these companies. The smallest OCI items, even the average value can be negative is the profit/loss of financial assets available for sale, this is because this OCI item has the highest changes or fluctuations compared to other items. The fluctuation occurs if in a period the value is positive with a high amount, but in the next period, it drops dramatically so the value is negative. 
Table 2 presents a description and correlation between research variables.

Table 2. Descriptive statistics and correlations between variables

\begin{tabular}{|c|c|c|c|c|c|c|c|c|}
\hline \multirow[b]{2}{*}{ Variable } & \multicolumn{3}{|c|}{ Descriptive Statistics } & \multicolumn{5}{|c|}{ Pearson Correlation } \\
\hline & $\begin{array}{c}\text { Mean } \\
\text { (million, } \\
\text { IDR) }\end{array}$ & $\begin{array}{l}\text { Mean } \\
\text { (scale) }\end{array}$ & $\begin{array}{l}\text { Std. } \\
\text { Dev. }\end{array}$ & NI & OCI & $\mathrm{CI}_{\mathrm{t}+1}$ & Attribution & Size \\
\hline NI & 671.245 & 0,0689 & 0,1050 & 1 & $0,067(0,005)^{*}$ & $0,484(0,000)^{*}$ & $0,504(0,000)$ & $-0,075(0,002)$ \\
\hline OCI & 14.978 & 0,0138 & 0,0465 & $0,067(0,005)^{*}$ & 1 & $0,011(0,639)$ & $0,097(0,000)$ & $-0,078(0,001)$ \\
\hline FOREX & (33.672) & 0,0017 & 0,0128 & $0,000(0,987)$ & $0,272(0,000)^{*}$ & $-0,018(0,442)$ & $0,037(0,115)$ & $0,005(0,839)$ \\
\hline REVAL & 395.459 & 0,0041 & 0,0034 & $-0,011(0,641)$ & $0,524(0,000)^{*}$ & $-0,015(0,519)$ & $0,135(0,000)$ & $-0,048(0,041)$ \\
\hline JABAR & 15.455 & 0,0004 & 0,0045 & $0,020(0,388)$ & $0,079(0,001)^{*}$ & $-0,017(0,468)$ & $-0,018(0,436)$ & $-0,032(0,179)$ \\
\hline LINDUNG & 18.431 & 0,0016 & 0,0014 & $0,006(0,787)$ & $0,075(0,003)^{*}$ & $0,025(0,296)$ & $0,005(0,820)$ & $0,103(0,000)$ \\
\hline PASTI & 1.419 & 0,0010 & 0,0081 & $0,014(0,567)$ & $0,310(0,000)^{*}$ & $-0,003(0,883)$ & $-0,008(0,737)$ & $-0,047(0,047)$ \\
\hline $\mathrm{CI}_{\mathrm{t}+1}$ & 649.819 & 0,0847 & 0,0167 & $0,484(0,000)^{*}$ & $0,011(0,639)$ & & $0,771(0,000)$ & $-0,090(0,000)$ \\
\hline CIPEI & 660.650 & 0,0726 & 0,0148 & $0,504(0,000)^{*}$ & $0,097(0,000)^{*}$ & $0,771(0,000)^{*}$ & 1 & $-0,099(0,000)$ \\
\hline Size & 19.248 .661 & 6,3287 & 0,8819 & $-0,075(0,002) * *$ & $-0,078(0,001)^{*}$ & $-0,090(0,000)^{*}$ & $-0,099(0,000)$ & 1 \\
\hline Industry & - & 0,53 & 0,0591 & $-0,028(0,245)$ & $-0,030(0,211)$ & $-0,037(0,121)$ & $-0,057(0,016)$ & $0,025(0,289)$ \\
\hline LOSS & - & 0,42 & 0,0412 & $0,150(0,000)^{*}$ & $0,043(0,073)$ & $0,069(0,004)^{*}$ & $0,092(0,000)$ & $-0,093(0,000)$ \\
\hline
\end{tabular}

$\mathrm{N}: 1.835 ; *$ Significant at $1 \%, * * 5 \%$, and $* * * 10 \%$.

$\mathrm{NI}$ is positively correlated with aggregate $\mathrm{OCI}, \mathrm{CI}_{\mathrm{t}+1}$ and $\mathrm{CI}$ attribution (significant at $1 \%$ ), and negatively correlated with firm size (significant at 5\%). The results show, the greater the net profit generated, the greater the comprehensive income and profit attributions to the owner. But, the larger the size of the company, the net profit generated by NI decreases (coefficient of -0.075 , significant at $5 \%$ ), as well as the CI (coefficient of -0.090 , significant at $1 \%$ ). This is because, in this research period, many companies with large assets experienced a net loss or a very small profit to total asset ratio (ROA). Although in aggregate OCI is positively correlated with NI, when $\mathrm{OCI}$ is decomposed, none of the significant OCI components correlate with NI.

Aggregate OCI is positively correlated with NI, significant at $1 \%$ level. The greater the NI, the greater the aggregate OCI, and vice versa. This because, when companies experienced profits in one period, the OCI was also positive in that period. Likewise, when a company experiences a net loss, the $\mathrm{OCI}$ is also negative even though the causes of the NI and OCI are different. Meanwhile, the larger the size of the company, the OCI will also decrease. All OCI component items are positively correlated with OCI aggregates, significant at $1 \%$.

The item that closely related to OCI is the revaluation of fixed assets (as indicated by the highest Pearson correlation coefficient among others), followed by the pension benefit items, and financial assets available for sale. Revaluation of fixed assets is positively and significantly correlated because the nominal value of revaluation is very high compared to other OCI items. The same result is also for pension benefit items because this item occur every period in each company. However, asset revaluation is negatively correlated with SIZE (correlation coefficient of -0.048 at the 5\% significance level), meaning that company size does not guarantee the frequency of revaluation of fixed assets, including the amount in monetary value (in IDR) of the revaluation. Revaluation relates more to business sectors (the correlation with the type of industry is 0.086 , significant at $1 \%$ ), and the type of companies that report revaluation are property and banking.

Comprehensive income $\mathrm{CI}_{t+1}$ has a very significant positive correlation with attribution to owners (coefficient of correlation is 0.77 , at a significance of $1 \%$ ), as well as net income NI (coefficient of correlation is 0.504 at a significance of $1 \%$ ). The greater the $\mathrm{NI}$ and $\mathrm{CI}_{\mathrm{t}+1}$ profits generated by the company, the greater the portion attributable to the owners of the parent. NI was also significantly positively correlated with $\mathrm{CI}_{\mathrm{t}+1}$ (correlation coefficient 0.484 , significant at $1 \%$ level). This is because the proportion of NI and CI are greater than OCI and also the nature of NI is 
relatively more stable, while $\mathrm{OCI}$ is very volatile and uncertain.

Meanwhile, attribution to the owner also has a positive correlation with LOSS (coefficient is 0.092 , significant at $1 \%$ ). This shows that attributions of profit to the owner are still made regardless of NI and CI are positive or experiencing negative (means loss). Attribution to the owner is negatively correlated with SIZE (coefficient of -0.099 is significant at $1 \%$ ), this means that the size of the company does not guarantee the amount of NI and CI profits distributed to the owners of the parent entity.

Industry type (as one of the control variables) was measured by a dummy variable, a score of 1 if it includes a manufacturing company, and a score of 0 if it includes a service and trade company. The industrial type control variable has a mean value of 0.53 . This means that $53 \%$ of the data are manufacturing companies. While the control variable, LOSS, is also measured by a dummy variable, a score of 1 if NI is negative or experiencing a loss, and a score of 0 if vice versa. The LOSS, as a control variable has a mean value of 0.42 . This means that $42 \%$ of the companies sampled suffered losses or negative NI.

The assumption test was done to make sure that the data in this study eligible for normality, homoscedasticity test, autocorrelation, and multicollinearity problem. A normality test was done using a non-parametric test-one sample Kolmogorov-Smirnov test. The result showed that the data was normally distributed based on the Asymp.Sig. (2-tailed) which was more than or equal to 0.05 .

Homosedasticity test was performed to see whether there is a similarity in the variance of the independent variable error in the four models of this study. The results of data processing show that all data in 4 models were free from heteroscedasticity. The technique used Park Test, the regression of residuals/errors. Meanwhile, an autocorrelation test was performed using Watson Durbin Test. The data was free from autocorrelation based on the Durbin-Watson value that was in the range of 2-4 at a significance level of 5. Whereas the multicollinearity test was conducted to see whether there was a very strong relationship between the independent variables in the four models of this study. The technique used was a linear regression analysis - colinearity diagnostics. The result showed that data was free from multicollinearity because the VIF value was less than 4 . Thus, the data met the prerequisite test analysis, making it feasible to be used in proving hypotheses with multiple linear regression analysis.

There were four hypotheses of this study, according to the problems formulated, hypothesis testing was done by multiple linear regression analysis. F test was done to see whether the model being built has feasibility. T-test was conducted to see the direction and magnitude of the influence of independent variables (NI, OCI, attribution, size, loss, and industry) on the dependent variable (comprehensive income in period $t+1$ ). The significance level of both the $\mathrm{F}$ test and the t-test was set at $1 \%, 5 \%$, and $10 \%$. A summary of the results of the multiple regression analysis for the four models is presented in the following table:

Table 3. Analysis of multiple linear regression

\begin{tabular}{|c|c|c|c|c|c|}
\hline & Model 1 & Model 2 & Model 3.a & Model 3.b & Model 4 \\
\hline Intercept & $0,1047(0,000)^{*}$ & $0,9472(0,000)^{*}$ & $0,1096(0,000)^{*}$ & $0,2019(0,582)$ & $0,2003(0,000) *$ \\
\hline $\mathrm{NI}_{\mathrm{t}}$ & $0,768(0,000) *$ & $0,803(0,000) *$ & $0,774(0,000) *$ & - & - \\
\hline $\mathrm{OCI}_{\mathrm{t}}$ & $-0,093(0,216)$ & $-0,146(0,116)$ & $0,(0)$, & - & - \\
\hline $\mathrm{NI} * \mathrm{CIPEI}_{\mathrm{t}}$ & - & $0,562(0,000)^{*}$ & $0,(0)$, & - & - \\
\hline $\mathrm{OCI}^{*} \mathrm{CIPEI}_{\mathrm{t}}$ & - & $0,131(0,736)$ & $0,(0)$, & - & - \\
\hline $\mathrm{NI}_{\mathrm{t}-1}$ & - & - & $0,532(0,000)^{*}$ & - & - \\
\hline $\mathrm{NI}_{\mathrm{t}-2}$ & - & - & $0,341(0,029)^{* *}$ & - & - \\
\hline $\mathrm{NI}_{\mathrm{t}-3}$ & - & - & $-0,022(0,383)$ & - & - \\
\hline $\mathrm{CI}_{\mathrm{t}}$ & - & - & - & $0,421(0,000)^{*}$ & - \\
\hline $\mathrm{CI}_{\mathrm{t}-1}$ & - & - & - & $0,007(0,828)$ & - \\
\hline $\mathrm{CI}_{\mathrm{t}-2}$ & - & - & - & $0,015(0,589)$ & - \\
\hline $\mathrm{CI}_{\mathrm{t}-3}$ & - & - & - & $-0,175(0,003)^{*}$ & - \\
\hline FOREX & - & - & - & - & $\begin{array}{c}-0,230 \\
(0,045) * *\end{array}$ \\
\hline
\end{tabular}




\begin{tabular}{|c|c|c|c|c|c|}
\hline REVAL & - & - & $\begin{array}{lll}- & - \\
-1\end{array}$ & - & - 0,100 (0,384) \\
\hline JABAR & - & - & - & - & - 0,077 (0,376) \\
\hline LINDUNG & - & - & - & - & $0,040(0,144)$ \\
\hline PASTI & - & - & - & - & $0,316(0,036)^{* *}$ \\
\hline SIZE & $-0,011(0,007)$ & $\begin{array}{c}0,010 \\
(0,019)^{* * *}\end{array}$ & $-0,007(0,014)^{* *}$ & $0,007(0,223)$ & - 0,518 (0,000) \\
\hline LOSS & $-0,320(0,708)$ & $0,113(0,190)$ & $0,074(0,015)$ & $0,032,(0,065)$ & - 0,011 (0,231) \\
\hline INDUSTRY & $-0,773(0,273)$ & $-0,112(0,117)$ & $0,061(0,016)$ & $0,044(0,008)^{* * *}$ & - 0,013 (0,318) \\
\hline F-Statistic & $110,296(0,000)^{*}$ & $91,704(0,000)^{*}$ & $93,494(0,000)^{* *}$ & $67,696(0,000)^{*}$ & $93,143(0,005)^{*}$ \\
\hline Adjusted $\mathrm{R}^{2}$ & 0,235 & 0,274 & 0,281 & 0,214 & 0,207 \\
\hline \multicolumn{6}{|c|}{ 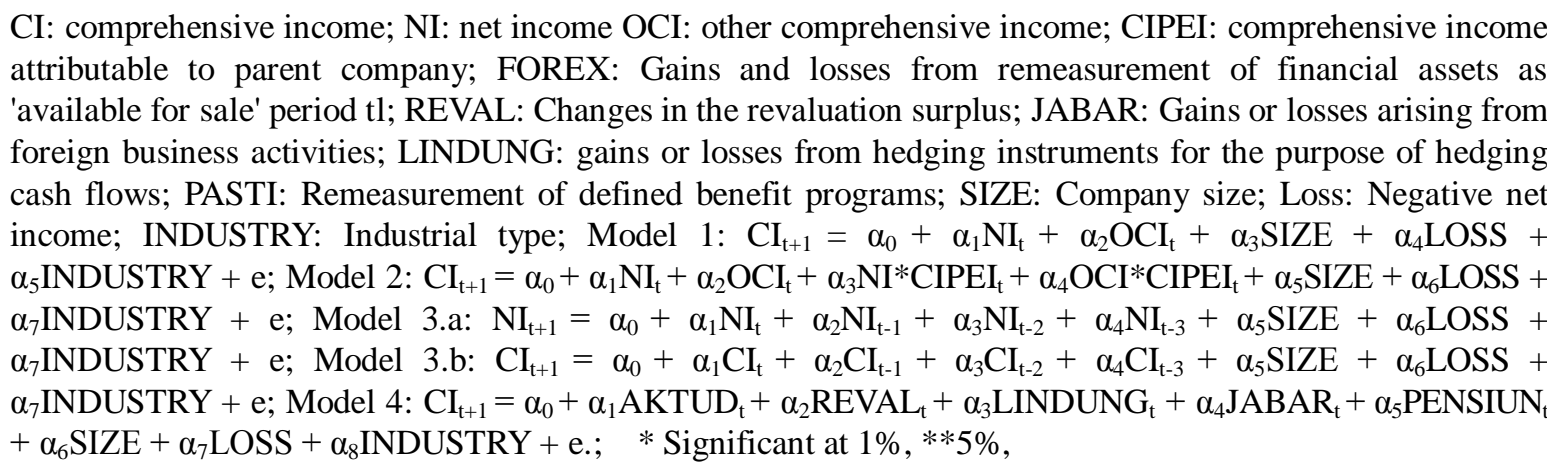 } \\
\hline
\end{tabular}

Table 3 and the summary in Table 4 (below) show that the F-statistic model 1 is 110.296 with a significance of 0,000 (significant at $1 \%$ level). This means that model 1 is fit so that it meets the requirements to predict the influence between variables. Results obtained from the subsequent analysis that $\mathrm{H} 1$ was accepted. This conclusion was based on the results obtained that $\mathrm{NI}$ and $\mathrm{OCI}$ can predict $\mathrm{CI}$ in the future. Coefficient of NI is 0.768 with a significance of 0.000 , significant at $1 \%$ level, and coefficient of OCI is -0.093 , with a significance of 0.216 (mean not significant). This means that NI is better able to predict future CIs than OCI, where the NI coefficient was greater, sig t below the level of $1 \%$ and positively correlated, while the OCI coefficient was smaller, negative and insignificant. The following table summarizes the outputs of multiple linear regression analysis that was used as a basis for accepting or rejecting the four hypotheses built:

Table 4. Summary of hypothesis testing

\begin{tabular}{|c|c|c|c|c|}
\hline Hypothesis & $\begin{array}{c}\text { The basis for accepting } \\
\text { hypotheses }\end{array}$ & Model & Test result & Conclusion \\
\hline $\begin{array}{l}\text { H1: NI and OCI are } \\
\text { able to predict CI } \\
\text { in the future. }\end{array}$ & $\begin{array}{l}\text { - F value of model } 1 \text { is } \\
\text { significant. } \\
\text { - The coefficients of NI } \\
\text { and OCI are significant. }\end{array}$ & Model 1 & $\begin{array}{l}\text { Sig F model } 1=110,296(0,000)^{*} . \\
\text { NI coefficient }=0,768(0,000)^{*} \\
\text { CI Coefficient }=-0,093(0,216) .\end{array}$ & $\begin{array}{l}\mathrm{H} 1 \\
\text { accepted }\end{array}$ \\
\hline $\begin{array}{l}\text { H2: Presentation of } \\
\text { CI attribution can } \\
\text { improve the } \\
\text { ability of NI and } \\
\text { OCI in predicting } \\
\text { future CI. }\end{array}$ & $\begin{array}{l}\text { - F value of model } 1 \text { and } \\
\text { model } 2 \text { are significant. } \\
\text { - Adjusted } \mathrm{R}^{2} \text { model } 2> \\
\text { adjusted } \mathrm{R}^{2} \text { model } 1 . \\
\text { - The coefficient of NI } \\
\text { model } 2>\text { coefficient } \\
\text { of NI model } 1 . \\
\text { - The coefficient of OCI } \\
\text { model } 2>\text { the } \\
\text { coefficient OCI model }\end{array}$ & $\begin{array}{l}\text { Model } 1 \\
\text { and } 2\end{array}$ & $\begin{array}{l}\text { Sig F of model } 1=110,296(0,000)^{*} . \\
\text { Sig F of model } 2=91,704(0,000)^{*} \text {. } \\
\text { Adjusted } \mathrm{R}^{2} \text { of model } 2=0,274 . \\
\text { Adjusted } \mathrm{R}^{2} \text { of model } 1=0,235 . \\
\text { The coefficient of. NI model } 2=0,803 \\
(0,000)^{*} \text {. } \\
\text { The Coefficient of NI model } 1=0,768 \\
(0,000)^{*} \text {. } \\
\text { The Coefficient of OCI model } 2=\end{array}$ & $\begin{array}{l}\mathrm{H} 2 \\
\text { accepted }\end{array}$ \\
\hline
\end{tabular}




\begin{tabular}{|c|c|c|c|c|}
\hline & \multirow[t]{2}{*}{1.} & & \multicolumn{2}{|l|}{$-0,146(0,116)$} \\
\hline & & & $\begin{array}{l}\text { The Coefficient of. OCI model } 1= \\
-0,093(0,216) \text {. }\end{array}$ & \\
\hline $\begin{array}{l}\text { H3: } \mathrm{CI} \text { is more } \\
\text { persistent than } \\
\text { NI. }\end{array}$ & $\begin{array}{l}\text { - F value of model } 3 \mathrm{~b} \text { and } \\
\text { model } 3 \mathrm{a} \text { are significant. } \\
\text { - Adjusted } \mathrm{R}^{2} \text { model } 3 \mathrm{~b}> \\
\text { adjusted } \mathrm{R}^{2} \text { model } 3 \mathrm{a} \text {. }\end{array}$ & $\begin{array}{l}\text { Model } 3 a \\
\text { and } 3 b\end{array}$ & $\begin{array}{l}\text { Sig. F of model } 3 a=93,494(0,000)^{*} \text {. } \\
\text { Sig F of model } 3 b=67,696(0,000)^{*} \text {. } \\
\text { Adjusted } \mathrm{R}^{2} \text { of model } 3 a=0,281 \\
\text { Adjusted } \mathrm{R}^{2} \text { of model } 3 b=0,214\end{array}$ & $\begin{array}{l}\mathrm{H} 3 \\
\text { rejected. }\end{array}$ \\
\hline $\begin{array}{l}\text { H4: Remeasurement } \\
\text { of defined } \\
\text { benefit program } \\
\text { has the highest } \\
\text { predictive power } \\
\text { for future CIs, } \\
\text { compared to the } \\
\text { other four OCI } \\
\text { components. }\end{array}$ & $\begin{array}{l}\text { The variable coefficient } \\
\text { of retirement benefits is } \\
\text { larger and significant } \\
\text { compared to the other } \\
\text { four OCI items. }\end{array}$ & Model 4 & $\begin{array}{l}\text { Sig F of model } 4=93,143(0,005)^{*} \\
\text { Coefficient and sig. of } \mathrm{t} \text { : } \\
\text { FOREX }=-0,230(0,045)^{* *} \\
\text { REVAL }=-0,100(0,384) \\
\text { LINDUNG }=-0,077(0,376) \\
\text { JABAR }=0,040(0,144) \\
\text { PASTI }=0,316(0,036)^{* *}\end{array}$ & $\begin{array}{l}\mathrm{H} 4 \\
\text { accepted }\end{array}$ \\
\hline
\end{tabular}

$*$ Significant at $1 \%, * * 5 \%$,

Table 3 and Table 4 show that Sig F model $1=110,296(0,000)$ and Sig F model $2=91,704(0,000)$, thus model 1 and model 2 that were built meet the fitness requirements of the model, and the results are: $\mathrm{H} 2$ is accepted. This means that attribution of profit to the owner can moderate the influence of NI and OCI on future CIs. NI period $t$ dominantly influences the $\mathrm{CI}$ of the next period compared to other independent variables, both in model 1 and model 2. The increase in the NI and OCI coefficients from model 1 to model 2 showed that the moderation variable attributing CI to the owner was able to increase the ability of NI and OCI in predicting the future of CI. The coefficient of the NI from model $2=0.803(0,000)$, this result was greater than the NI coefficient of model $1=0.768$ $(0,000)$. The OCI coefficient of model $2=-0.146(0.116)$ was greater than the OCI coefficient of model $1=-0.093$ (0.216). However, because the OCI coefficient was not significant in either model 1 or 2, moderation of the CI attribution was only able to improve the ability of the NI to predict future CIs, and not for OCI. NI was more capable of predicting CI than OCI, both with and without attribution moderation variables to the owner, due to the unstable nature of OCI.

Table 3 and Table 4 also show that the F-statistic model 3.a is 93,494 (0,000)** and model 3.b is 67,696 (0,000)*. Adjusted R2 model 3.a of 0.281 and model 3.b of 0.214 , this shows that both models meet the feasibility of the model, and model 3.a (NI) is more persistent than model 3.b (CI), or H3 is rejected. The relatively stable nature of NI for each period causes NI to be more persistent than CI, wherein the CI contained in OCI is affected by the unstable $\mathrm{OCI}$ and was not necessarily present in every period and every company. Table 7 and Table 8 inform that F-statistic model 4 is $93,143(0.005) *$ and adjusted R2 is 0.207 , this shows that model 4 meets the model's eligibility.

The regression equation from model 4 formed as follows:

$\mathrm{CI}_{\mathrm{t}+1}=0,200-0,230$ FOREX $-0,100$ REVAL $-0,077 \mathrm{JABAR}+0,040$ LINDUNG + 0,316 PENSIUN $-0,518$ SIZE $+0,011$ LOSS - 0,013 INDUSTRY.

Detailed OCI presentations have more relevance than aggregate presentations. When OCI was tested in the aggregate in models 1 and 2, both did not significantly influence CI. However, when OCI was decomposed into items in model 4 , there were OCI items that have a significant effect. The most dominant pension benefit program has a positive effect with a coefficient of 0.316 at a level of $5 \%$, thus $\mathrm{H} 4$ is accepted. While the gains and losses on financial assets have a negative effect with a coefficient of 0.23 at a $5 \%$ level.

\subsection{Discussion of Result of the Research}

With regards to data of companies going public in Indonesia, this study provides empirical evidence that NI and OCI are simultaneously able to predict future CIs, but NI coefficients are higher and more significant than OCI. This means that the predictive power of NI is greater than OCI. This is because in the composition of CI, the percentage of NI is higher than OCI, or the value of NI in rupiah is higher than OCI. NI is real as realized revenue and results of management performance, whereas OCI is not due to management performance. This is because market volatility causes volatility in the difference between the carrying value of an asset and its fair value. These results support 
research (Banks et al., 2018) in Australia, (Rees \& Shane, 2012) in America and (Kanagaretnam et al., 2009) in Canada, where OCI has no significant effect on earnings. NI is more predictive than CI in predicting future earnings.

OCI does not correlate with performance. If users of financial statements are not careful, information about CI can be misleading. For example in the sample with the IBST Code, the high value of CI (and ultimately its impact on equity balance) is due to the very high asset revaluation (amounting to Rp.761 million) when compared to the value of NI (which only amounted to Rp. 146 million). Revaluation rarely appears, but occasionally it appears, its value is very high, far above the NI. As a result, revaluation greatly influences the value of CI and a large gap arises between NI and $\mathrm{CI}$ in that period. Another example was the sample financial statements with the MDKI code for the 2018 period, the sample with the MEGA code, and there are still a few more.

OCI fluctuations are very high and unstable. The value of OCI in a period with a positive value and large amount, it can change drastically into a large negative value in next period. For example in one sample, for OCI items, the profit (loss) of financial assets available for sale, in 2017 amounted to IDR 70.4 billion and in 2018 dropped dramatically by negative IDR 8.6 million. Likewise in the other sample, for OCI items: post-employment benefits, in 2017 "only" IDR 490 million, in 2018 increase to IDR 4.5 billion, and many other similar cases. OCI does not exist every year (for example fixed assets revaluation items and financial statement translation), and not all OCI items are owned by companies (for example OCI items in the form of financial statement translation and cash flow hedges) are very rarely owned. OCI items are the most widely owned by companies is a definite reward, because it is required by law. Whereas NI is obtained every year in each company.

Additional information of earnings attributions to shareholders on the presentation of a comprehensive income statement has been proven to be able to simultaneously increase the ability of NI and $\mathrm{OCI}$ in predicting future CIs (H2 accepted). But partially, only a significant NI can predict CI after being moderated by the attribution of earnings to the owner. Additional earnings attribution information was not sufficient to moderate the influence of OCI on future CIs. Once again, this is due to the nature of OCI which has very high volatility, and not necessarily every item is in every company, whereas NI which is relatively stable, exists in every company and every period. In addition, attributable ownership of the parent entity can increase the influence of NI in predicting CI, because the composition of the ownership of the parent entity (majority and controlling) is far above the attribution of non-controlling interests (minority). In almost all companies in Indonesia, shares owned by the public are very small (under 5\%). Information on the income statement is more transparent and the reader can see how much profit allocation is attributed to the shareholders, in this case, the owner of the parent entity and non-controlling interests. Attention and protection are given to minority shareholders or non-controlling interests. Even though the composition of share ownership is small and is not involved in controlling the entity, it is still given comprehensive information related to attributing profit and attributing equity to it. Besides, there is a strong positive correlation between NI, CI and the attribution of CI to the owner of the parent entity (see table 4.2 descriptive statistics and correlations), the greater the NI and CI, the greater the amount of NI and OCI attributed to the parent entity owner, including when NI and CI suffer losses or are negative.

$\mathrm{NI}$ is more persistent than $\mathrm{CI}$ (H3 is rejected), because NI values are more stable, while CIs containing OCI are highly fluctuating. This is due to the OCI value which is influenced by large external conditions, such as macroeconomic fundamentals, stock price movements, which impact on the difference in the carrying value of assets with their fair value. OCI is also influenced by how many items and the nominal amount the company has of OCI components. Not all OCI items are company-owned and every period exists. This is different from NI, which must exist in every company and every period. The NIt coefficient in model $3 \mathrm{a}$, and the CIt coefficient in model $3 \mathrm{~b}$ are greatest compared to the previous period's NI and CI coefficients. This means that the NI and CI of the period influence on the NI and CI of the next period.

OCI items that have the greatest nominal value are the revaluation of fixed assets, OCI items that are most widely held by companies are retirement benefits, while OCI items that are the most volatile are gains or losses on financial assets, and OCI items that are least frequently owned are cash flow hedges. Regarding the relevance of financial assets available for sale, in line with some previous research, the pension benefit program items are in contrast to previous research outside of Indonesia. In Australia, the most relevant OCI item is cash flow hedges (Banks et al., 2018), as well as in America (Rees \& Shane, 2012), in Iran the most relevant is the revaluation of fixed assets (Steinberg \& Forscher, 2014), in Canada is the profit loss of financial assets (Kanagaretnam et al., 2009) and in Malaysia are the profit loss of financial assets and asset revaluation (Yousefi Nejad \& Ahmad, 2017).

The OCI item with the greatest regression coefficient (significant effect) is the post-employment defined benefit program ( $\mathrm{H} 4$ accepted). These findings indicate that all companies must have a defined benefit plan that is reported in each reporting period. In Indonesia, a defined benefit program is an obligation that is regulated in law so that go public companies are required to have OCI items. These results also indicate the very important role of regulators in determining the regulations that companies must comply with in order to fulfill stakeholder interests. 


\section{Conclusion and Suggestion}

\subsection{Conclusion}

Based on the discussion of the hypothesis, it can be concluded that other comprehensive income information and profit attribution to the owners of the parent company and non-controllers, in general, can increase the value of relevance for the user. This is indicated by the ability of information in the income statement that net income (NI), other comprehensive income (OCI), comprehensive income (CI), attribution of net income and attribution of comprehensive income to owners of the parent entity and non-controlling prior period in predicting comprehensive income in the future. Thus, the results of this study support the policies of the Financial Accounting Standards Board and the Indonesian Institute of Accountants in changing the format of the presentation of the income statement by adding OCI information and attributing earnings to owners. However, when viewed partially, net income (NI) is more relevant (more able to predict) than other comprehensive income or other comprehensive income (OCI), with or without moderation attributable earnings to the owner. Thus, this study supports the policy of the Financial Accounting Standards Board and the Indonesian Institute of Accountants that earnings per share (EPS) are still calculated based on NI, not from CI or OCI. Likewise, EPS is only calculated based on the number of shares of the owner of the parent entity, without involving non controlling interest or the number of both.

The study also concluded that the OCI item remeasurement program rewards must have the highest predictive power for future CIs, compared to the other four OCI components, because each company has these items for the applicable regulatory obligations. OCI fixed assets revaluation items is item with the largest rupiah value, although the frequency of occurrence in the income statement is rare. The types of property and infrastructure companies are the companies that have the most items. The most volatile OCI items are financial assets available for sale, and types of financial companies such as banking, insurance, and financing are companies that have many of these items. Item OCI yang paling langka adalah lindung nilai arus kas dan jenis perusahaan pembiayaan yang memiliki item ini paling banyak. Selain itu, penelitian ini juga menyimpulkan bahwa ukuran perusahaan berkorelasi negatif dengan NI, OCI, dan atribusi. Ukuran perusahaan tidak menjamin NI, OCI, dan atribusi kepada pemilik dengan nilai tinggi.

\subsection{Suggestion for Future Researchers}

The measurement of the value of relevance in this study was only based on the ability to predict future earnings. Related to investment returns, such as the predictive power of future cash flows and dividends that have not been done, this is a gap for further research. For this reason, it is recommended that further research include these variables.

\section{References}

Authors, F. (2015). Article information: Introduction. Journal of Documentation, An Application Of Language Processing For A Search Interface, 24. Retrieved from https://www.emeraldinsight.com/doi/abs/10.1108/eb026897

Banks, L., Hodgson, A., \& Russell, M. (2018). The location of comprehensive income reporting - does it pass the financial analyst revision test?. Accounting Research Journal, 31(4), 531-550. https://doi.org/10.1108/ARJ-04-2017-0075

Bao, M. X., \& Unlu, E. (2017). Does the Variability of Other Comprehensive Income (OCI) Play a Role in the Determination of Cost of Debt, Capital Structure and Credit Ratings?. SSRN Electronic Journal. https://doi.org/10.2139/ssrn.2939958

Būmane, I. (2018). The Methodology Of The Statement Of Comprehensive Income And Its Impact On Profitability: The Case Of Latvia. Entrepreneurship And Sustainability Issues, 0282(1), 77-86. https://doi.org/10.9770/jesi.2018.6.1(6)

Canina, L., \& Potter, G. (2019). Determinants of Earnings Persistence and Predictability for Lodging Properties. Cornell Hospitality Quarterly, 60(1), 40-51. https://doi.org/10.1177/1938965518791729

Chambers, D. J., \& Linsmeier, T. J. S. C. (2007). No Title. Review of Accounting Studies, 12(4), 557-593.

Chebaane, S., \& Ben, H. (2014). The impact of IFRS adoption on value relevance of earnings and book value of equity: the case of emerging markets in African and Asian regions. Procedia Social and Behavioral Sciences, 145, 70-80. https://doi.org/10.1016/j.sbspro.2014.06.012

Chen, E., \& Gavious, I. (2016, November). Unrealized earnings, dividends and reporting aggressiveness: an examination of firms' behavior in the era of fair value accounting, 56, 217-250.

Dimaggio, P. J., Powell, W. W., \& Powell, W. W. (2012). GRIMALDI Evolution of the Insects.pdf. American Sociological Review, 48(2), 147-160.

Ding, Z. (2019). Other Comprehensive Income, Auditor Practice Experience and Audit Pricing, $233-252$. 
https://doi.org/10.4236/ajibm.2019.91015

Doukakis, L. C. (2010). The persistence of earnings and earnings components after the adoption of IFRS. Managerial Finance, 36(11), 969-980. https://doi.org/10.1108/03074351011081286

Du, N., \& Stevens K. J. M. (2015). No Title. Accounting Research Journal, 28(3), 284-299.

Elbakry, A. E., Nwachukwu, J. C., \& Abdou, H. A. (2017). Comparative evidence on the value relevance of IFRS-based accounting information in Germany and the UK. Journal of International Accounting, Auditing and Taxation, 28, 10-30. https://doi.org/10.1016/j.intaccaudtax.2016.12.002

Fanani, Z. (2010). Analisis Faktor-Faktor Penentu Persitensi. Jumal Akuntansi Dan Keuangan Indonesia, 7, 109-123.

Francesco, S. (2018). The value relevance of consolidated and separate financial statements: Are non-controlling interests relevant?. African Journal of Business Management, 12(11), 329-337. https://doi.org/10.5897/ajbm2017.8335

Fujianti L., \& Satria, I. (2020). Firm Size, Profitability, Leverage as Determinants of Audit Report Lag: Evidence From Indonesia. International Journal of Financial Research, 11(2). https://doi.org/10.5430/ijfr.v11n2p61

Gazzola, P., \& Amelio, S. (2014, March). The Impact of Comprehensive Income on the Financial Ratios in a Period of Crises. Procedia Economics and Finance, 12, 174-183. https://doi.org/10.1016/s2212-5671(14)00333-5

Hafij Ullah Mohammad, A. (2013). Article Information: Abstract. Journal of Financial Reporting and Accounting, 8(539), 2015.

Hodgson, A., \& Russell, M. (2014). Comprehending Comprehensive Income. Australian Accounting Review, 24(2), 100-110. https://doi.org/10.1111/auar.12022

Humayun Kabir, M., \& Laswad, F. (2011). Properties of net income and total comprehensive income: New Zealand evidence. Accounting Research Journal, 24(3), 268-289. https://doi.org/10.1108/10309611111187000

Ikatan Akuntan Indonesia (IAI). (2018). Standar Akuntansi Keuangan Efektif per 1 Januari 2018. Dewan Standar Akuntansi Keuangan, Jakarta.

Jensen, M., \& Meckling, W. (1976). Theory of the firm: Managerial behaviour, agency costs and ownership. Strategic Management Journal, 21(4), 1215-1224. Retrieved from http://search.ebscohost.com/login.aspx?direct=true \&db=buh\&AN=12243301\&site=ehost-live

Jones, D. A., \& Smith, K. J. (2011). Comparing the value relevance, predictive value, and persistence of other comprehensive income and special items. Accounting Review, 86(6), 2047-2073. https://doi.org/10.2308/accr-10133

Kanagaretnam, K., Mathieu, R., \& Shehata, M. (2009). Usefulness of comprehensive income reporting in Canada. Journal of Accounting and Public Policy, 28(4), 349-365. https://doi.org/10.1016/j.jaccpubpol.2009.06.004

Khan, S., \& Bradbury, M. E. (n.d.). The volatility of comprehensive income and its association with market risk. (January 2015).

Kim, H. J., \& Yoon, S. S. (2019). Value-relevance of the regulatory non-GAAP adjustments in the Korean banking industry. Asia-Pacific Journal of Accounting and Economics, 26(1-2), 160-171. https://doi.org/10.1080/16081625.2019.1546974

Kim, J. H. (2016). Presentation formats of other comprehensive income after accounting standards update 2011-05. Research in Accounting Regulation, 28(2), 118-122. https://doi.org/10.1016/j.racreg.2016.09.009

Kubota, K., Suda, K., \& Takehara, H. (2011). Information content of other comprehensive income and net income: Evidence for Japanese firms. Asia-Pacific Journal of Accounting and Economics, 18(2), 145-168. https://doi.org/10.1080/16081625.2011.9720879

Kumari, P., \& Mishra, C. S. (2018). Equity Values and Prediction of Earnings with Disaggregation of Earnings in India. Global Business Review. https://doi.org/10.1177/0972150918779167

Lewellen, J., \& Resutek, R. J. (2019). Why do accruals predict earnings?. Journal of Accounting and Economics. https://doi.org/10.1016/j.jacceco.2018.12.003

Lin, W., \& Rong, M. (2012). Impacts of other comprehensive income disclosure on earnings management. Nankai Business Review International, 3(1), 93-101. https://doi.org/10.1108/20408741211201944

Lopes, A. I., Lourenço, I., \& Soliman, M. (2013). Do alternative methods of reporting non-controlling interests really matter?. Australian Journal of Management, 38(1), 7-30. https://doi.org/10.1177/0312896212458788 
López-Quesada, E., Camacho-Miñano, M. del M., \& O. Idowu, S. (2018). Corporate governance practices and comprehensive income. Corporate Governance (Bingley), 18(3), 462-477. https://doi.org/10.1108/CG-01-2017-0011

Marchini, P. L., \& D’Este, C. (2015, January). Comprehensive Income and Financial Performance Ratios: Which Potential Effects on RoE and on Firm's Performance Evaluation?. Procedia Economics and Finance, 32(2009), 1724-1739. https://doi.org/10.1016/s2212-5671(15)01478-1

Moghaddam, A. N., \& Aslani, D. (2018). Impacts of Cash Dividend Components on Earning Persis- tence and Return on Stock, 3(1), 53-67.

Nam, S. (2019). The role of accruals in the prediction of future earnings. Journal of Accounting and Finance, 19(7), 1-34, https://doi.org/10.33423/jaf.v19i7.2571

Rees, L. L., \& Shane, P. B. (2012). Academic research and standard-setting: The case of other comprehensive income. Accounting Horizons, 26(4), 789-915. https://doi.org/10.2308/acch-50237

Sajnóg, A. (2017). The role of comprehensive income in predicting banks' future earnings based on the practice of banks listed on the Warsaw Stock Exchange. Equilibrium, 12(3). https://doi.org/10.24136/eq.v12i3.26

Saymeh, A. A., Khalaf ALkhazaleh, A. M., \& Musallam, E. M. (2019). The Impact of Other Comprehensive Income Items on Financial Performance: Case of Jordanian Commercial Banks. The Journal of Social Sciences Research, 5(54), 1216-1228. https://doi.org/10.32861/jssr.54.1216.1228

Schaberl, P. D., \& Victoravich, L. M. (2015). Reporting location and the value relevance of accounting information: The case of other comprehensive income. Advances in Accounting, 31(2), 239-246. https://doi.org/10.1016/j.adiac.2015.09.006

Shi, L., Wang, P., \& Zhou, N. (2017). Enhanced disclosure of other comprehensive income and increased usefulness of net income: The implications of Accounting Standards Update 2011-05. Research in Accounting Regulation, 29(2), 139-144. https://doi.org/10.1016/j.racreg.2017.09.005

So, S., \& Smith, M. (2009). Value relevance of IAS 27 (2003) revision on presentation of non-controlling interest: Evidence from Hong Kong. Journal of International Financial Management and Accounting, 20(2), 166-198. https://doi.org/10.1111/j.1467-646X.2009.01029.x

Sun, J. (2019). A Stock Selection Method Based on Earning Yield Forecast Using Sequence Prediction Models. Retrieved from http://arxiv.org/abs/1905.04842

Veltri, S., \& Ferraro, O. (2018). Does other comprehensive income matter in credit-oriented systems? Analyzing the Italian context. Journal of International Accounting, Auditing and Taxation, 30, 18-31. https://doi.org/10.1016/j.intaccaudtax.2017.12.006

Willett, R. J. (2016). University of Canterbury, New Zealand. Journal of Contemporary Accounting \& Economics. https://doi.org/10.1016/j.jcae.2016.09.005

Yahaya, K. A., Fagbemi, T. O., \& Oyeniyi, K. K. (2015). No Title. Journal of Agricultural Economics, Environment and Social Sciences, 1(1). Retrieved from http://www.unimaid.edu.ng/jaeess

Yan, C., \& He, H. (2018). Non-controlling Large Shareholders and Firm Performance in China. Asia-Pacific Journal of Financial Studies, 47(3), 401-425. https://doi.org/10.1111/ajfs.12216

Yousefi Nejad, M., \& Ahmad, A. (2017). Value Relevance of available-for-sale financial instruments (AFS) and revaluation surplus of PPE (REV) components of other comprehensive income. SHS Web of Conferences, 34, 03004. https://doi.org/10.1051/shsconf/20173403004

Zhao, X., Zhao, K., \& Wei, W. (2018). Earnings Management using Other Comprehensive Income Items: A Multi-Case Study on Chinese Listed Companies, (Ssah), 198-201.

\section{Copyrights}

Copyright for this article is retained by the author(s), with first publication rights granted to the journal.

This is an open-access article distributed under the terms and conditions of the Creative Commons Attribution license (http://creativecommons.org/licenses/by/4.0/). 